\title{
PRODUK IMPOR YANG TIDAK MEMILIKI LABEL HALAL BERDASARKAN UNDANG-UNDANG NO. 33 TAHUN 2014 TENTANG JAMINAN PRODUK HALAL
}

\author{
oleh: \\ Fasya Putri Ramdhani \\ Eni Dasuki Suhardini, S.H., M.H
}

\begin{abstract}
ABSTRAK
Produk impor saat ini sudah semakin berkembang dan menjadi kebutuhan masyarakat mulai dari pangan, kosmetik, sampai obat-obatan. Banyaknya produk impor yang menarik perhatian konsumen ini disebabkan karena kemajuan teknologi yang pesat serta mudah untuk diakses oleh masyarakat. Namun keberadaan produk impor juga tidak terlepas dari ketidakadaan label halal yang tercantum pada suatu produk, ini menjadi perhatian karena masyarakat Indonesia yang mayoritas beragama Islam. Tentu hal ini menjadi perhatian masyarakat selaku konsumen yang akan menggunakan ataupun mengkonsumsi produk impor, baik untuk konsumen yang muslim maupun nonmuslim, karena permasalahan halal saat ini bukan hanya berhubungan dengan muslim. Maka yang perlu diperhatikan ialah bagaimana perlindungan dan kepastian hukum terhadap konsumen serta pengawasan terhadap produk impor yang tidak memiliki label halal. Karena dalam Pasal 4 UUJPH menyebutkan produk yang diperdagangkan di wilayah Indonesia wajib bersertifikat halal. Perlindungan sebagai bentuk jaminan hukum terhadap masyarakat selaku konsumen dapat dilakukan dengan mensosialisasikan kepada masyarakat secara aktif agar selalu berhati-hati dalam memilih produk impor. Serta memberikan edukasi agar masyarakat mengetahui ciri-ciri produk impor yang telah melalui proses pengujian sertifikasi, baik melalui lembaga yang terlibat maupun menggunakan media sosial yang memberi dampak signifikan. Berupaya untuk melakukan penindakan terhadap pelaku usaha agar senantiasa bertanggung jawab atas produknya. Dan yang paling penting ialah segera menerbitkan Peraturan Pemerintah (PP) sebagai payung hukum dalam melaksanakan sistem jaminan halal. Pengawasan terhadap keberadaan produk impor dilakukan dengan standarisasi produk secara internasional agar memudahkan dalam kerjasama internasional, serta melakukan pembaruan sertifikat termasuk pengujian kembali proses produk halal kepada pelaku usaha untuk menjaga konsistensi kehalalan produknya untuk mencegah perubahan proses produk halal. Juga ketentuan mengenai keharusan mencantumkan keterangan tidak halal harus dipertegas agar dapat dilaksanakan, seluruh bentuk pengawasan ini tentu akan berjalan dengan maksimal jika negara turut serta mendukung pengawasan sistem produk halal.
\end{abstract}

Kata Kunci : Produk impor, label halal, Sistem Jaminan Halal

\section{PENDAHULUAN}

\section{Latar Belakang}

Produk impor kini sudah semakin banyak beredar di Indonesia dimana produk impor tersebut sudah menjadi bagian penting atau tidak terlepas dari kehidupan masyarakat mulai dari pangan, obat-obatan, kosmetik dan lain sebagainya. Sebagian besar masyarakat seringkali mudah tergiur untuk mengkonsumsi dan menggunakan produk impor "kekinian". Hal ini disebabkan oleh globalisasi yang didukung dengan kemajuan teknologi sehingga masyarakat selaku konsumen mempunyai banyak pilihan dalam memenuhi kebutuhannya.

Banyaknya produk impor yang beredar terdapat pula produk yang keberadaannya menimbulkan kekhawatiran bagi sebagian besar masyarakat Indonesia, karena tidak adanya label halal yang tercantum pada produk impor tersebut. Hal ini menjadi perhatian karena mayoritas masyarakat Indonesia beragama Islam yang mana ini menjadi sangat penting 
keberadaannya, sehingga ini dapat mengakibatkan masyarakat selaku konsumen menjadi khawatir dalam mengkonsumi maupun menggunakan suatu produk impor. Juga masih terdapat produk-produk impor yang beredar di masyarakat belum terjamin kehalalannya yang dibuktikan dengan banyak ditemukannya kasus-kasus kehalalan produk.

Halal merupakan salah satu aspek yang sangat penting dalam kehidupan seorang muslim. Namun, dalam dunia yang modern ini permasalahan kehalalan suatu produk menjadi masalah yang kompleks. Hal ini dikarenakan adanya proses yang belum jelas status kehalalannya dan sulit dimengerti oleh masyarakat umum. ${ }^{1)}$

Al Qur'an menyatakan bahwa halal dan haram merupakan sesuatu yang sangat prinsip dalam Islam karena didalamnya terkait hubungan antara manusia dengan Allah. UndangUndang Dasar Negara Republik Indonesia Tahun 1945 mengamanatkan Negara menjamin kemerdekaan tiap-tiap penduduk untuk memeluk agamanya masing-masing dan untuk beribadah menurut agama dan kepercayaannya itu, juga memberikan perlindungan dan jaminan tentang kehalalan produk yang dikonsumsi dan digunakan masyarakat.

Tujuan tersebut menjadi penting mengingat kemajuan teknologi dan ilmu pengetahuan di bidang pangan, obat-obatan, dan kosmetik berkembang pesat. Hal itu berpengaruh secara nyata pada pergeseran pengolahan dan pemanfaatan bahan baku untuk makanan, minuman, kosmetik, obat-obatan serta produk lainnya dari yang semula bersifat sederhana dan alamiah menjadi pengolahan dan pemanfaatan bahan baku hasil rekayasa ilmu pengetahuan. Hal ini memungkinkan percampuran antara yang halal dan yang haram baik disengaja maupun tidak.

Pencantuman label halal pada produk impor semakin diperlukan melihat Potensi Pasar Produk Halal sebagai berikut $:^{2}$

1. Pertumbuhan permintaan produk halal dunia 9,5\% dari 2 triliun USD (2013) menjadi 3,7 triliun USD tahun 2019

2. Jumlah penduduk dunia tahun 2013 adalah 7.021.836.029 (kurang lebih 1,57 milyar beragama islam)

3. Di Asia Tenggara, pemeluk agama islam $>250$ juta

4. Konsumsi muslim global tumbuh 1.2626 miliar USD (2018), sekitar 17,4\% dari total konsumsi dunia

5. Indonesia konsumen terbesar produk halal, 197 miliar USD, Turki (100 miliar USD), Pakistan (93 miliar USD) dan Mesir (88 miliar USD).

Payung hukum tentang label halal produk impor ialah adanya Undang-Undang No. 33 Tahun 2014 tentang Jaminan Produk Halal (selanjutnya disingkat UUJPH). Dalam Pasal 4 UUJPH yang menyebutkan bahwa produk yang masuk, beredar, dan diperdagangkan di wilayah Indonesia wajib bersertifikat halal.

Salah satu contoh kasus yang sempat menghebohkan masyarakat Indonesia tentang produk impor yang tidak memiliki label halal namun keberadaannya cukup diminati oleh masyarakat Indonesia, ialah Mie instan asal Korea yaitu Samyang. Beberapa waktu lalu Badan Pengawas Obat dan Makanan (BPOM) menyatakan 4 produk mie instan asal Korea positif mengandung babi sehingga harus ditarik dari pasaran oleh importir. Yaitu Samyang (U- Dong), Samyang (Kimchi), Nongshim, dan Ottogi, yang diimpor oleh PT Koin Bumi. Di luar itu ada produk Samyang yang berlogo halal, tapi bukan versi MUI dimana sertifikasi halal merupakan kewenangan dari Majelis Ulama Indonesia (selanjutnya MUI) itu sendiri. ${ }^{3)}$

1) Anna Priangani Roswiem, Buku Saku Produk Halal Makanan dan Minuman, Republika Penerbit, Jakarta, 2015, hlm. 1.

2) Siti Aminah, "Implementasi Undang - Undang Nomor 33 Tahun 2014 tentang Jaminan Produk Halal”, Makalah seminar Registrasi dan Sertifikasi Halal BPJPH, Jakarta, 8 September 2017, hlm. 7.

3) https://kumparan.com/@,kumparannews/label-halal-korea-di-mi-samyang-belum-diakui-di-indonesia (diakses pada 20 Desember 2017) 
Diketahui bahwa mie instan Samyang ada yang mencantumkan label halal, namun label halal tersebut diterbitkan oleh Lembaga halal luar negeri mie tersebut diproduksi yaitu Korea. Label halal yang berasal dari luar negeri belum tentu halal di Indonesia. Dalam website resmi MUI, daftar Lembaga Korea itu belum ada yang diakui di Indonesia. Setiap negara mempunyai Lembaga sertifikasi halal masing-masing sehingga standar proses sertifikasi setiap negara belum tentu sama.

\section{Identifikasi Masalah}

1. Bagaimana perlindungan serta jaminan hukum terhadap masyarakat selaku konsumen terkait adanya produk impor yang tidak memiliki label halal?

2. Bagaimana pengawasan terhadap keberadaan produk impor yang tidak mencantumkan label halal ataupun keterangan tidak halal pada produk?

\section{TINJAUAN PUSTAKA}

\section{Pengertian Produk Halal}

Pengertian produk (product) menurut Kotler dan Armstrong adalah segala sesuatu yang dapat ditawarkan ke pasar untuk mendapatkan perhatian, dibeli, digunakan, atau dikonsumsi yang dapat memuaskan keinginan atau kebutuhan. ${ }^{4}$ Suatu produk harus memiliki keunggulan dari produk-produk yang lain baik dari segi kualitas, desain, bentuk, ukuran, kemasan, pelayanan, garansi, dan rasa agar dapat menarik minat konsumen untuk mencoba dan membeli produk tersebut, termasuk juga tanda halal.

Kata halal berasal dari bahasa Arab yang berarti "melepaskan" dan "tidak terikat", secara etimologis halal berarti hal-hal yang boleh dan dapat dilakukan karena bebas atau tidak terikat dengan ketentuan-ketentuan yang melarangnya. ${ }^{5)}$ Atau diartikan segala sesuatu yang bebas dari bahaya duniawi dan ukhrawi.

Ma'ruf Amin menyatakan bahwa makanan halal-haram bukan hanya masalah umat muslim saja, melainkan juga berkaitan dengan masyarakat luas pada umumnya, karena halal itu bukan sekedar halal, tetapi higienis, bersih, sehat, dan bermanfaat. Hal ini sejalan dengan ketentuan syariat islam yang menegaskan bahwa tujuan dan tugas hidup manusia yang pertama dan utama di muka bumi ini adalah untuk beribadah dan mengabdi kepada Allah. Lantas bagaimana mungkin ibadah seseorang dan do'a seseorang dapat diterima oleh Allah, jika makanan dan minumannya tidak suci dan tidak baik. ${ }^{6)}$ Selain itu industri halal Indonesia yang jauh tertinggal dari negara-negara lain, pelaku usaha Indonesia belum menganggap industri halal sebagai peluang bisnis penting. Padahal kenyataannya sekarang, industri halal sedang menjadi tren global di dunia.

Produk halal berdasarkan Pasal 1 angka 2 UUJPH adalah produk yang telah dinyatakan halal sesuai dengan syariat islam. Produk yang memenuhi syarat sesuai syariat islam antara lain :7)

1. Tidak mengandung babi dan bahan yang berasal dari babi.

2. Tidak mengandung bahan-bahan yang diharamkan seperti bahan-bahan yang berasal dari organ manusia, darah, dan kotoran.

3. Semua bahan yang berasal dari hewan yang disembelih menurut tata cara syariat islam. MUI, 2013.

4) Philip Kotler, Op.Cit, hlm. 346.

5) Ibid, hlm. 146 .

6) Ma'ruf Amin, "Halal Berlaku Untuk Seluruh Umat", Jurnal Halal No 1 Th XVI, Jakarta, LPPOM

7) Departemen Agama Ri, Panduan Sertifikasi Halal, Direktorat Jenderal Bimbingan Masyarakat Islam dan Penyelenggara Haji, Jakarta, 2008, hlm. 2. 
4. Semua tempat penyimpanan, tempat penjualan, tempat pengolahan, tempat pengolahan dan transportasi tidak boleh digunakan untuk babi dan/atau barang tidak halal lainnya. Jika pernah digunakan untuk babi dan/atau barang tidak halal lainnya terlebih dahulu harus dibersihkan dengan tata cara syariat islam.

5. Semua makanan dan minuman yang tidak mengandung khamar (minuman keras).

Pasal 18 Undang-Undang Jaminan Produk Halal (UUJPH) pun mengatur tentang bahan yang haram. Dalam Pasal 18 ayat (1) menyebutkan bahwa bahan yang berasal dari hewan yang diharamkan meliputi :

a. bangkai;

b. darah;

c. babi; dan/atau

d. hewan yang disembelih tidak sesuai dengan syariat.

Al-Qur'an menjelaskan bahwa makanan yang diharamkan pada pokoknya hanya ada empat yaitu sebagaimana dalam surat Al Baqarah ayat 173 :

Artinya: "Sesungguhnya Allah hanya mengharamkan bagimu (memakan) bangkai, darah, daging babi, dan binatang yang ketika disembelih disebut (nama) selain Allah. Akan tetapi, barang siapa dalam keadaan terpaksa (memakannya) sedang ia tidak menginginkannya, tidak (pula) melampaui batas, maka sesungguhnya Allah Maha Pengampun, Maha Penyayang".

Ayat ini menjelaskan bahwa makanan yang diharamkan diantaranya $:^{8)}$

1. Bangkai, yang termasuk bangkai adalah hewan yang mati dengan tidak disembelih termasuk didalamnya hewan yang mati tercekik, dipukul, jatuh, ditanduk, dan diterkam oleh hewan buas, kecuali yang sempat kita menyembelihnya, hanya bangkai ikan dan belalang saja yang boleh kita makan.

2. Darah, sering pula diistilahkan dengan darah yang mengalir, maksudnya adalah darah yang keluar pada waktu penyembelihan (mengalir) sedangkan darah yang tersisa setelah penyembelihan yang ada pada daging setelah dibersihkan dibolehkan. Dua macam darah yang dibolehkan yaitu jantung dan limpa.

3. Babi, apapun yang berasal dari babi hukumnya haram baik darahnya, dagingnya, maupun tulangnya.

4. Binatang yang ketika disembelih menyebut nama selain Allah.

Hadits Rasulullah Saw juga menerangkan tentang hal tersebut :

"Sesungguhnya Allah tidak menerima kecuali hal-hal yang baik, dan sesungguhnya Allah memerintahkan kepada orang-orang mu'min sebagaimana yang diperintahkan para rasul".

Allah berfirman dalam Q.S Al Baqarah ayat 172 : "Hai orang-orang yang beriman, makanlah diantara rezeki yang baik-baik, yang kami berikan kepadamu dan bersyukurlah kepada Allah, jika benar-benar kepada-Nya kamu menyembah”.

Beliau kemudian mencontohkan seorang laki-laki, dia telah menempuh perjalanan jauh, rambutnya kusut, serta berdebu, ia menengadahkan tangannya ke langit : "Yaa Rabbi! Ya Rabbi! Sedangkan ia memakan makanan yang haram, dan pakaiannya yang ia pakai dari harta yang haram, dan ia meminum dari minuman yang haram, dan dibesarkan dari hal-hal yang haram, bagaimana mungkin akan diterima do'anya”. (HR.Muslim).

8) Qammarudin Shaleh, Ayat-ayat Larangan dan Perintah Dalam Al-Qur'an Pedoman Menuju Akhlak Muslim, CV Penerbit Diponegoro, Bandung, 2004, hlm. 476. 
Kesimpulan yang dapat diambil dari pernyataan tersebut bahwa syarat-syarat produk halal menurut syariat islam adalah $:{ }^{9}$

a. Halal dzatnya yaitu makanan yang dari dasarnya halal untuk dikonsumsi, dan telah ditetapkan kehalalannya oleh Al-Qur'an dan hadits.

b. Halal cara memperolehnya, yaitu makanan yang diperoleh dengan cara yang baik dan sah. Makanan akan menjadi haram apabila cara memperolehnya dengan jalan yang batil (salah) karena itu bisa merugikan orang lain dan dilarang oleh syari'at.

C. Halal dalam memprosesnya, yaitu makanan yang semula halal dan akan menjadi haram apabila cara pengolahannya tidak sesuai dengan syariat agama.

d. Halal dalam penyimpanannya, yaitu makanan yang halal tidak disimpan bersentuhan dengan yang haram.

e. Halal dalam pengangkutannya, yaitu makanan yang dalam proses pengangkutannya tidak boleh bersama-sama dengan makanan yang haram.

f. Halal dalam penyajiannya, yaitu makanan agar tidak disajikan bersama dengan yang haram.

Syarat-syarat halal tersebut bukan hanya untuk makanan, namun juga pada kosmetika, karena kosmetika termasuk produk yang telah menjadi kebutuhan manusia pada umumnya. Bahwa pada perkembangannya tekonologi telah mampu menghasilkan berbagai produk kosmetika yang menggunakan bahan, serta memiliki fungsi yang beragam, yang seringkali bahannya tidak jelas.

Mengenai hal ini MUI telah mengeluarkan fatwa Nomor 26 Tahun 2013 tentang Standar Kehalalan Produk Kosmetika dan Penggunaannya, dengan ketentuan hukum sebagai berikut :10)

1. Penggunaan kosmetika untuk kepentingan berhias hukumnya boleh dengan syarat :

a. bahan yang digunakan halal dan suci;

b. ditujukan untuk kepentingan yang dibolehkan secara syar'i; dan

c. tidak membahayakan.

2. Penggunaan kosmetika dalam (untuk dikonsumsi/ masuk ke dalam tubuh) yang menggunakan bahan yang najis atau haram hukumnya haram.

3. Penggunaan kosmetika luar (tidak masuk ke dalam tubuh) yang menggunakan bahan yang najis atau haram selain babi diperbolehkan dengan syarat dilakukan penyucian setelah pemakaian (tathhir syar'i).

4. Penggunaan kosmetika yang semata-mata berfungsi tahsiniyyat, tidak ada rukhsah (keringanan) untuk memanfaatkan kosmetika yang haram.

5. Penggunaan kosmetika yang berfungsi sebagai obat memiliki ketentuan hukum sebagai obat, mengacu pada fatwa terkait obat-obatan.

6. Produk kosmetika yang mengandung bahan yang dibuat dengan menggunakan mikroba hasil rekayasa genetika yang melibatkan gen babi atau gen manusia hukumnya haram.

7. Produk kosmetika yang menggunakan bahan (bahan baku, bahan aktif, dan/atau bahan tambahan) dari turunan hewan halal (berupa lemak atau lainnya) yang tidak diketahui cara penyembelihannya hukumnya makruh tahrim, sehingga harus dihindari.

8. Produk kosmetika yang menggunakan bahan dari produk mikrobial yang tidak diketahui media pertumbuhan mikrobanya apakah dari babi, harus dihindari sampai ada kejelasan tentang kehalalan dan kesucian bahannya.

9) Departemen Agama, Tanya Jawab Seputar Produk Halal, Direktorat Jenderal Bimbingan Masyarakat Islam dan Penyelenggaraan Haji, Jakarta, hlm. 17.

10) Tim Penyusun : Majelis Ulama Indonesia, Himpunan Fatwa MUI Sejak 1975, Erlangga, Jakarta, 2015, hlm. 8 . 
Jaminan kehalalan suatu produk dapat diwujudkan diantaranya dalam bentuk sertifikat halal yang menyertai suatu produk, yang dengan sertifikat tersebut produsen dapat mencantumkan logo halal pada kemasannya. Masalahnya, bagaimana menjamin bahwa setifikat halal tersebut telah memenuhi kaidah syariat yang ditetapkan dalam penetapan kehalalan suatu produk. ${ }^{11)}$

\section{Pengertian Produk Impor}

Amir MS menjelaskan bahwa kegiatan impor adalah memenuhi kebutuhan masyarakat akan barang-barang dengan cara mendatangkan barang yang belum tersedia dalam negeri dari luar negeri. ${ }^{12)}$ Atau dapat dikatakan impor adalah kegiatan memasukkan barang ke dalam daerah pabean. Perusahaan atau perorangan yang melakukan kegiatan impor tersebut disebut importir. ${ }^{13)}$

Proses impor umumnya adalah tindakan memasukkan barang atau komoditas dari negara lain ke dalam negeri. Impor barang secara besar umumnya membutuhkan campur tangan dari bea cukai di negara pengirim maupun penerima. Sebagaimana dalam perjanjian umum, perjanjian ekspor impor berkaitan dengan hak dan kewajiban para pihak yang terlibat. Eksportir berkewajiban memberikan barang kepada importir dan berhak menerima pembayaran dari importir. Importir berkewajiban melakukan pembayaran kepada eksportir dan berhak menerima barang dari eksportir. ${ }^{14)}$

Undang-Undang No.10 Tahun 1995 tentang kepabeanan Pasal 1 angka 13 menjelaskan bahwa impor adalah kegiatan memasukkan barang ke dalam wilayah pabeanan.

Pelaksana impor-ekspor dapat dibagi dalam 5 kelompok sebagai berikut: ${ }^{15}$ )

a. Kelompok Indentor

Jika kebutuhan suatu barang tidak dapat dipenuhi dari kegiatan produksi di dalam negeri, suatu negara terpaksa harus mengimpor barang dari luar negeri. Tidak semua pemakai barang impor melaksanakan kegiatan impornya sendiri. Tapi sebagian besar pelaksanaan impor tersebut mereka percayakan pada perusahaan yang sudah biasa melakukan kegiatan impor. Maksudnya, para pemakai barang impor ini melakukan kegiatan ini. oleh karena itu, para pemakai barang impor tersebut disebut "indentor".

b. Kelompok Importir

Importir memikul tanggung jawab kontrak atas terlaksananya dengan baik barang yang diimpor. Ini berarti importir memikul risiko atas segala sesuatu mengenai barang yang diimpor baik risiko kerugian, kerusakan, keterlambatan dari barang yang di pesan, termasuk risiko penipuan dan manipulasi. Para importir ini pada umumnya terdiri dari :

1. Pengusaha Impor

Badan usaha yang diberi izin oleh pemerintah dalam bentuk Tanda Pengenal Pengakuan Importir (TPPI) untuk mengimpor barang yang khusus disebut dalam izin tersebut.

2. Approved Importer/ Approved Traders

Importir yang mendapatkan perlakuan istimewa dari pemerintah-Departemen Perdaganan untuk mengimpor komoditas tertentu dan untuk tujuan tertentu pula yang dipandang perlu oleh pemerintah.

${ }^{11)}$ Anton Apriyantono Nurbowo, Panduan Belanja dan Konsumsi Halal, Khairul Bayan, Jakarta, 2003, hlm. 24 2014, hlm. 8 .

12) Amir MS, Strategi Memasuki Pasar Impor, Penerbit PPM, Jakarta, 2004, hlm. 139.

13) Adrian Sutedi, Hukum EKspor Impor, Raih Asa Sukses (Penebar Swadaya Group), Jakarta Timur,

14) Ibid:

15) Amir MS, Ekspor Impor: Teori \& Penerapannya, Penerbit PPM, Jakarta, 2007, Hlm. 61. 
3. Importir Terbatas

Untuk memudahkan dan memperlancar usaha dari perusahaan-perusahaan Penanaman Modal Asing (PMA) atau Penanaman Modal Dalam Negeri (PMDN), pemerintah memberikan izin khusus pada perusahaan tersebut untuk mengimpor sendiri mesin dan bahan baku yang diperlukan. Tentu saja dengan kemudahan bea masuk (bukan untuk diperdagangkan lagi). Izin ini diberikan dalam bentuk Angka Pengenal Importer Terbatas dan dikeluarkan oleh BKPM (Badan Koordinasi Penanaman Modal) atas nama Menteri Perdagangan.

4. Importir Umum

Badan usaha yang melakukan impor bermacam-macam komoditas, juga disebut sebagai Pesero Niaga atau Perusahaan Dagang Negara.

5. Sole Agent Importer

Perusahaan PMA yang berdiri di Indonesia dan memasarkan produknya harus mempunyai perwakilan atau menunjuk suatu agen tunggal yang akan mewakili dalam usahanya menjual maupun mengimpor bahan baku dan suku cadangnya.

C. Kelompok Promosi

Kelompok ini pada umumnya terdiri dari Kantor Perwakilan dari produsen atau eksportir asing di negara konsumen atau importir.

d. Kelompok Eksportir

Para eksportir ini pada umumnya terdiri dari produsen eksportir, yang sebagian hasil produksinya memang diperuntukkan untuk pasar luar negeri, yang ekspornya diurus sendiri oleh produsen bersangkutan. Ini disebut sebagai produsen eksportir.

e. Kelompok Pendukung

Selain importir dan eksportir dalam pelaksana utama, terdapat pula badan usaha lain yang mempunyai peran penting dalam menunjang serta menjamin kelancaran pelaksanaan impor maupun ekspor, yang terdiri dari Bank-bank Devisa, dan Badan Usaha Transportasi.

Sebelum seseorang atau suatu perusahaan memutuskan untuk melakukan impor suatu barang, ada baiknya harus memiliki pengetahuan mengenai tatacara, peraturan, dan prosedur impor yang berlaku, khususnya di wilayah Kepabeanan Republik Indonesia. Pada tahap ini, calon importir harus mempersiapkan kelengkapan-kelengkapan yang berkaitan dengan perizinan.

Proses masuknya produk impor ke Indonesia bisa dilakukan oleh calon importir dengan dua macam cara, pertama importir dengan memakai L/C (Letter of Credit). L/C pada dasarnya adalah sebuah dokumen yang dikeluarkan oleh Bank devisa yang menjamin kemampuan nasabah untuk membayar barang atau jasa. Bank devisa tersebut menerbitkan atau mengeluarkan L/C atas nama importir atau buyer. Selain itu juga memberi hak atau wewenang kepada eksportir atau seller untuk mendapatkan pembayaran dan persyaratan yang tertuang dalam L/C telah terpenuhi tanpa adanya penyimpangan (discrepancy). ${ }^{16)}$

\section{PEMBAHASAN}

\section{Perlindungan dan Jaminan Hukum Pada Masyarakat Indonesia Terkait Label Halal Produk Impor}

Perlindungan dalam hal keberadaan produk impor yang tidak mencantumkan label halal atau keterangan tidak halal pada produknya merupakan suatu jaminan hukum yang

16) Andi Susilo, Buku Pintar Ekspor Impor Manajemen Tata Laksana \& Transportasi Internasional, Transmedia, Jakarta Selatan,2008, Hlm. 67. 
seharusnya didapatkan oleh masyarakat selaku konsumen atas setiap produk yang dikonsumsi atau digunakan dari pelaku usaha atau produsen. Dengan adanya UUJPH yang berarti sebagai bentuk pemberian perlindungan hukum dalam memenuhi segala hak kepada konsumen untuk memberikan rasa aman kepada masyarakat. Dengan kata lain perlindungan hukum itu sebagai suatu gambaran dari fungsi hukum itu sendiri yang mempunyai konsep bahwa hukum itu memberikan kepastian, ketertiban, kemanfaatan, kedamaian, serta keadilan.

Perlindungan hukum dalam hal ini juga dijelaskan dalam Pasal 4 Undang-Undang Perlindungan Konsumen (selanjutnya UUPK) bahwa hak konsumen diantaranya yaitu hak atas keamanan kenyamanan keselamatan dalam mengkonsumsi barang/jasa, hak mendapatkan informasi yang benar, hak untuk mendapat bantuan hukum, dsb. Sebab masyarakat selaku konsumen memiliki resiko yang lebih besar daripada pelaku usaha, terkait adanya produk yang tidak mencantumkan label halal atau keterangan tidak halal karena dapat berdampak juga pada kesehatan baik dalam jangka pendek maupun panjang. Sementara pelaku usaha hanya mendapat kerugian berupa pemberian sanksi atas kelalaiannya, sehingga dapat dikatakan hak konsumen lebih rentan disebabkan posisinya yang lemah.

Perlindungan terhadap masyarakat diartikan sebagai segala upaya yang menjamin adanya kepastian pemenuhan hak konsumen sebagai wujud perlindungan hukum yang mengatur upaya perlindungan terhadap masyarakat. Hukum yang berlaku di Indonesia tersebut menyatakan bahwa produk yang masuk dan beredar di Indonesia wajib mencantumkan label halal, sebagaimana dalam Pasal 4 UUJPH. Dengan adanya perlindungan sebagai bentuk jaminan hukum terhadap masyarakat dengan tujuan agar masyarakat menjadi tidak ragu-ragu dan khawatir dengan komposisi yang terkandung dalam suatu produk, khususnya produk impor yang keberadaan perusahaannya tidak ada di dalam negeri.

Peranan perlindungan kepada masyarakat dapat dilakukan dengan selalu aktif menghimbau dan mensosialisasikan untuk selektif dalam mengkonsumsi dan menggunakan suatu produk, selalu memperhatikan yang bersertifikasi halal maupun yang label halalnya masih diragukan. Juga memberikan edukasi kepada masyarakat bagaimana ciri-ciri suatu produk yang telah melalui proses pengujian sertifikasi secara resmi, baik melalui lembaga yang terkait ataupun melalui sarana media sosial yang dapat memberikan efek yang sangat signifikan terhadap perkembangan suatu produk. Karena dengan adanya label halal menunjukan bahwa suatu produk impor tersebut layak untuk dikonsumsi atau digunakan baik oleh umat muslim maupun non muslim.

Jaminan hukum dalam hal ini merupakan suatu bentuk kepastian hukum terhadap kehalalan suatu produk yang dibuktikan dengan sertifikat halal sebagaimana diatur dalam Pasal 1 angka 5 UUJPH. Pemerintah dituntut untuk dapat memberikan kepastian hukum terhadap masyarakat atas adanya produk impor.

Di Indonesia penyelenggaraan jaminan produk halal setelah diterbitkannya UUJPH pada Tahun 2014, menjadi kewenangan BPJPH atau dengan kata lain pemerintah yang mengambil alih dikeluarkannya sertifikat halal suatu produk hal ini menunjukan adanya transparansi antara pemerintah sebagai pihak yang berwenang untuk menjamin kepastian hukum dan keberadaan produk impor yang halal dan juga para pelaku usaha impor yang akan mengedarkan produknya di Indonesia.

Berdasarakan beberapa hal tersebut di atas, penulis berpendapat bahwa adanya UUJPH ini dirasa belum dapat digunakan secara maksimal dalam kehidupan sehari-hari yang disebabkan oleh belum adanya peraturan pemerintah dari Undang-Undang tersebut sebagai bentuk peraturan pelaksana dari jaminan produk halal, sementara kebutuhan pada saat ini menunjukkan bahwa lembaga jaminan produk halal tersebut memerlukan peraturan yang mengikat para pihak yang terlibat di dalamnya. Sehingga dirasa masih ada beberapa ketentuan yang "mengambang" untuk dilaksanakan. 
Belum adanya peraturan pelaksananya, dalam Undang-Undang tersebut juga kurang memberikan informasi bagaimana prosedur mengenai pemberian keterangan tidak halal pada suatu produk secara rinci, khususnya pada produk-produk impor yang akan masuk ke Indonesia, hal ini penting mengingat trend pasar impor sedang berkembang apalagi Indonesia sebagai negara yang mayoritas muslim harus dapat menyikapi hal ini dengan baik.

\section{Pengawasan terhadap Produk Impor yang Tidak Mencantumkan Label Halal}

Pengawasan terhadap produk impor dalam UUJPH diatur di Pasal 49 sampai dengan Pasal 52 mulai dari pengawasan yang dilakukan oleh BPJPH terhadap Jaminan Produk Halal hingga pengawasan dengan kementerian dan/atau lembaga terkait.

Proses pengawasan terhadap produk impor dapat dilakukan dengan standarisasi produk secara internasional, agar lebih memudahkan dalam melakukan kerjasama dalam hal keberadaan suatu produk impor di suatu negara. Standarisasi produk ini maksudnya ialah menetapkan syarat-syarat yang berlaku secara internasional agar setiap negara mempunyai patokan khusus dalam melakukan suatu kerjasama produk impor disamping ketentuanketentuan lain yang mengatur tentang kerjasama internasional.

Kerjasama internasional yang selama ini dilakukan dalam sistem jaminan produk halal yaitu berupa kerjasama saling pengakuan antar negara yang hendak melakukan kerjasama mengenai suatu produk impor, dimana bila antar negara sudah melakukan kerjasama saling pengakuan, maka label atau tanda halal yang diakui negara yang bersangkutan tidak perlu mengajukan sertifikasi halal kembali kepada lembaga jaminan produk halal, yang dalam hal ini adalah BPJPH, MUI dan juga pihak-pihak lain yang terlibat sebagaimana yang telah ditentukan dalam UUJPH.

Penulis berpendapat, hal ini akan menjadi lebih baik jika adanya standarisasi produk impor yang merupakan proses penentuan spesifikasi suatu produk yang berlaku secara internasional dalam mengajukan sertifikasi halal, sebab dengan adanya standarisasi produk secara internasional maka kerjasama antar negara akan menjadi lebih mudah karena sudah ada syarat-syarat sertifikasi halal secara internasional karena adanya kesamaan syarat-syarat mengenai ketentuan halal, sehingga setiap pelaku usaha impor tinggal mengikuti ketentuan tersebut. Karena jika hanya mengandalkan kerjasama internasional saling pengakuan, dimana setiap negara mempunyai ketentuan masing-masing dalam melakukan sertifikasi halal, maka tidak menutup kemungkinan jika suatu negara tidak dapat melakukan kerjasama saling pengakuan karena adanya perbedaan atau variasi dalam menangani masalah sertifikasi label halal melalui sistem jaminan halal.

Pengawasan selanjutnya dengan melakukan pembaruan sertifikat halal yang dibebankan pada pelaku usaha impor, termasuk di dalamnya pengujian kembali proses produk halal secara berkala. Hal ini demi menjaga konsistensi dari produk tersebut, dan untuk mencegah suatu produk yang hanya mengikuti prosedur produk halal diawal pada saat mengajukan syarat sertifikasi halal, namun setelah mendapatkan pengakuan halal berupa sertifikat halal proses pengolahan produk menjadi berubah dengan cara yang tidak sesuai.

Tidak menutup kemungkinan adanya oknum pelaku usaha impor yang tidak mau repot dan juga tidak mau rugi dalam mengeluarkan biaya lebih untuk proses produk halal. Karena tentu proses produk halal akan membutuhkan biaya yang lebih jika dibangingkan dengan suatu produk yang tidak melalui proses halal maupun prosedur-prosedur lain seperti izin edar dsb.

UUJPH Pasal 26 ayat (2) menyebutkan bahwa jika produk yang berasal dari bahan yang haram maka harus mencantumkan keterangan tidak halal pada produknya. Namun pada kenyataannya sedikit sekali atau sulit ditemukan produk yang mencantumkan keterangan tidak halal pada produknya. Disini penulis berpendapat perlu adanya penegasan antara pencantuman label halal dan keterangan tidak halal pada suatu produk, sebab jika kedua 
keterangan tersebut benar-benar perlu dan dibutuhkan masyarakat maka jangan hanya ketentuan yang tercantum dalam suatu Undang-Undang saja, namun benar-benar dilaksanakan dalam kehidupan sehari-hari, agar menjadi kepastian hukum dan juga dapat melaksanakan penegakan hukum apabila pelaku usaha tidak melaksanakan kewajibannya.

Keseluruhan pengawasan ini tentunya harus dilakukan oleh semua pihak, termasuk meningkatkan kerjasama internasional dimana setiap negara berekewajiban untuk melakukan pengawasan yang aktif sesuai dengan perannya masing-masing. Dengan begitu dapat meminimalisir keberadaan produk-produk impor yang tidak mencantumkan label halal, sehingga masyarakat selaku konsumen pun sudah tidak ragu-ragu dan khawatir dengan adanya produk impor serta komposisi yang terkandung didalamnya.

Sanksi juga merupakan bentuk pengawasan agar pelaku usaha impor mematuhi peraturan yang ada di Indonesia. Pemberian sanksi dapat berupa peringatan tertulis, denda administratif, dan pencabutan sertifikat halal. Para pelaku usaha impor harus menjaga kehalalan produknya dari hal-hal yang dapat membuat produk tersebut menjadi tidak halal.

Peraturan Pemerintah (PP) yang merupakan turunan dari UUJPH belum diterbitkan mengakibatkan lembaga jaminan produk halal tidak dapat berjalan secara maksimal. Sehingga pengawasan yang dilakukan BPJPH saat ini merupakan solusi peraturan sementara yang telah disosialisasikan oleh BPJPH dengan pihak terkait karena keadaan mendesak yaitu dengan mengakui sertifikat sebelumnya masih berlaku selama setahun, hal ini dilakukan agar tidak terjadi kendala dan menghambat masuknya barang impor. Berdasarkan ketentuan diatas dapat dikatakan bahwa peraturan sementara yang dikeluarkan oleh BPJPH ini sesuai dengan ketentuan dalam UUJPH sebagaimana dalam bagian ketentuan peralihan Pasal 58 dan 59.

\section{PENUTUP}

\section{Kesimpulan}

Perlindungan merupakan suatu jaminan hukum yang seharusnya didapatkan konsumen atas setiap produk yang dikonsumsi maupun digunakan. Perlindungan sebagai jaminan hukum menunjukan adanya fungsi dan tujuan tercapainya hukum, yang dalam hal ini adanya UUJPH. Hal ini dapat dilakukan dengan beberapa diantaranya aktif melakukan penghimbauan dan mensosialisasikan kepada masyarakat agar berhati-hati dalam memilih produk impor, serta memberikan edukasi agar mengetahui ciri-ciri serta proses suatu produk yang telah melalui pengujian sertifikasi. Melakukan tindakan penegakan terhadap pelaku usaha yang tidak bertanggung jawab atas produknya, sekaligus menerbitkan Peraturan Pemerintah (PP) sebagai payung hukum melaksanakan sistem jaminan halal. Perlindungan terhadap masyarakat selaku konsumen juga perlu dilakukan oleh lembaga dan pihak yang terlibat dalam sistem jaminan halal yang berbentuk kerjasama dalam hal memantau dan memeriksa proses sertifikasi. Semua bentuk perlindungan sebagai jaminan hukum kepada masyarakat ini tentu bertujuan agar masyarakat tidak lagi ragu-ragu dan khawatir dengan adanya produk impor, karena telah diberikan edukasi oleh pihak yang berwenang, hal ini tentu akan memenuhi hak selaku konsumen dan ketenangan pada pelaku usaha.

Pengawasan terhadap keberadaan produk impor yang tidak mencantumkan label halal atau keterangan tidak halal pada produk dengan melakukan standarisasi produk secara internasiona, sehingga akan memudahkan dalam melakukan kerjasama dalam hal proses produk impor. Ketentuan ini akan memperkuat kerjasama internasional saling pengakuan yang telah diatur dalam UUJPH, hal ini untuk menghindari perbedaan ketentuan diberbagai negara dalam hal menangani sertifikasi halal. Pengawasan juga dengan melakukan pembaruan sertifikasi termasuk pengujian kembali secara berkala yang dibebankan kepada pelaku usaha demi menjaga konsistensi dan kehalalan produknya. Hal ini untuk mencegah perubahan proses produk halal menjadi tidak halal yang dapat dilakukan oleh oknum pelaku usaha. Dan 
pengawasan secara maksimal harus dilakukan oleh semua pihak dalam kerjasama internasional diberbagai negara. Juga memberikan ketegasan pemberlakuan ketentuan mengenai keharusan mencantumkan keterangan tidak halal, agar dapat diaplikasikan dalam kehidupan sehari-hari. Pengawasan juga dilakukan dalam bentuk pemberian sanksi terhadap pelaku usaha impor yang tidak melakukan sertifikasi halal berupa peringatan tertulis, denda administratif, dan pencabutan sertifikat halal.

\section{Saran}

Pemerintah perlu segera menerbitkan Peraturan Pemerintah sebagai peraturan pelaksana dari UUJPH agar dapat diaplikasikan secara maksimal. Melakukan penghimbauan dan edukasi secara aktif kepada masyarakat agar teliti sebelum membeli dan mengetahui ciriciri produk yang telah melalui proses pengujian. Meningkatkan sumber daya manusia agar dapat bekerja dengan professionalitas yang baik khususnya dalam lingkungan internasional.

Melakukan peningkatan dukungan dan komitmen diantara negara-negara internasional dalam hal kerjasama internasional, juga dalam hal saling pengakuan lembaga halal, sehingga lembaga di setiap negara khususnya negara-negara impor produk halal terbesar yang menjadikan Indonesia sebagai sasaran negara pasar impor halal.

\section{DAFTAR PUSTAKA}

Adrian Sutedi, Hukum EKspor Impor, Raih Asa Sukses (Penebar Swadaya Group), Jakarta Timur, 2014

Amir MS, Strategi Memasuki Pasar Impor, Penerbit PPM, Jakarta, 2004

Andi Susilo, Buku Pintar Ekspor Impor Manajemen Tata Laksana \& Transportasi Internasional, Transmedia, Jakarta Selatan,2008

Anna Priangani Roswiem, Buku Saku Produk Halal Makanan dan Minuman, Republika Penerbit, Jakarta, 2015,

Anton Apriyantono Nurbowo, Panduan Belanja dan Konsumsi Halal, Khairul Bayan, Jakarta, 2003

Qammarudin Shaleh, Ayat-ayat Larangan dan Perintah Dalam Al-Qur'an Pedoman Menuju Akhlak Muslim, CV Penerbit Diponegoro, Bandung, 2004,

Departemen Agama Ri, Panduan Sertifikasi Halal, Direktorat Jenderal Bimbingan Masyarakat Islam dan Penyelenggara Haji, Jakarta, 2008

Departemen Agama, Tanya Jawab Seputar Produk Halal, Direktorat Jenderal Bimbingan Masyarakat Islam dan Penyelenggaraan Haji, Jakarta

Ma'ruf Amin, "Halal Berlaku Untuk Seluruh Umat", Jurnal Halal No 1 Th XVI, Jakarta, LPPOM MUI, 2013

Siti Aminah, "Implementasi Undang - Undang Nomor 33 Tahun 2014 tentang Jaminan Produk Halal", Makalah seminar Registrasi dan Sertifikasi Halal BPJPH, Jakarta, 8 September 2017, hlm. 7.

https://kumparan.com/@,kumparannews/label-halal-korea-di-mi-samyang-belum-diakui-diindonesia (diakses pada 20 Desember 2017)

Tim Penyusun : Majelis Ulama Indonesia, Himpunan Fatwa MUI Sejak 1975, Erlangga, Jakarta, 2015 